\title{
WHAT ARE THEIR WORDS WORTH? \\ POLITICAL Plans AND ECONOMIC PAINS OF \\ Fiscal CONSOLIDATIONS IN NEW EU \\ MEMBER STATES
}

\author{
JAN ZÁPAL \\ ONDŘEJ SCHNEIDER
}

CESIFO WORKING PAPER No. 1655

CATEGORY 1: PUBliC FINANCE

JANUARY 2006

An electronic version of the paper may be downloaded

- from the SSRN website:

www.SSRN.com

- from the CESifo website: www.CESifo-group.de 


\title{
WHAT ARE THEIR WORDS WORTH? POLITICAL Plans AND ECONOMIC PAINS OF Fiscal CONSOLIDATIONS IN NEW EU MEMBER STATES
}

\begin{abstract}
In this paper, we track fiscal authority behaviour in the ten new EU member states (NSM) in the period which immediately preceded their EU accession. We first present basic stylized facts about public budgets of those countries. The paper then analyses reasons which led to periods of fiscal consolidation in the NMS. Secondly, we also present evidence from PreAccession Economic and Convergence programmes of NMSs concerning planned steps of the fiscal authorities and try to contrast them with reality. Throughout the paper, we identify two different groups of countries which significantly differ in their fiscal behaviour. On the one side is the group of Baltic countries, displaying strong reform effort and responsible fiscal policy usually supported by strong economic growth. On the second extreme, we identify fiscally irresponsible central European countries and two Mediterranean islands displaying lax fiscal policies and little political will to implement costly reforms. Somewhere between stand Slovenia and Slovakia, first without a strong reform performance yet with budget deficits in compliance with the Stability and Growth Pact and later with recent reform efforts.

Our key finding concerning the behaviour of the fiscally irresponsible group of countries is that their current problems with high budget deficits originate in their lax approach and inability to implement politically costly expenditure cuts which is apparent from their revision of budget plans and endeavour to shift envisioned deficit reductions into the future. Yet, this strategy has led those countries to an uncomfortable position vis-à-vis European fiscal rules.
\end{abstract}

JEL Code: E6, E62, H6, H87.

Keywords: fiscal policy, new member states, consolidations, Stability and Growth Pact, excessive deficit procedure, convergence programmes.

\author{
Jan Zápal \\ Institute of Economic Studies \\ Charles University, Prague \\ Faculty of Social Sciences \\ Opletalova 26 \\ Czech Republic - 11001 Prague 1
}

\author{
Ondřej Schneider \\ Institute of Economic Studies \\ Charles University, Prague \\ Faculty of Social Sciences \\ Opletalova 26 \\ Czech Republic - 11001 Prague 1 \\ schneider@fsb.cuni.cz
}

\section{December 2005}

We would like to thank the following people for providing us with helpful comments, suggestions and documents: Marek Mora of European Commission for provision of PreAccession Economic Programmes of New Member States; Martin Gregor for helpful comments; Milena Horčicová for Czech Pre-Accession Economic Programmes and Drahomíra Vašková for help with the data sources. All remaining errors are the authors' responsibility. 


\section{INTRODUCTION}

Ten countries joined the European Union (EU) in May of 2004. ${ }^{1}$ All ten have declared that they will adopt the common European currency - the euro - as soon as possible. To that end, the ten must adjust their economic policies, namely monetary and fiscal policies. So far, it is fiscal policy that proves to be the more challenging. Some of the NMSs run fiscal deficits that are higher than the 3\% of GDP limit prescribed by the European Union's Stability and Growth Pact (SGP). Indeed, six out of the ten have found themselves in the Excessive Deficit Procedure (EDP) as soon as they entered the EU. ${ }^{2}$

The fiscal policy proves to be more difficult for authorities to control exactly because of its political connotations. Governments have found it very difficult to convince the electorates that fiscal consolidations are in their interest. Various governments have indeed collapsed amid fiscal reforms introduced or merely discussed.

Two groups of countries have emerged among the NMSs. Six out of the ten NMSs (Cyprus, Czech Republic, Hungary, Malta, Poland and Slovakia) did not manage to cut their general government deficits ${ }^{3}$ below $3 \%$ of GDP and thus has been found to violate prescripts of SGP and has been subsequently put under EDP in July 2004. ${ }^{4}$ Four countries (Estonia, Latvia, Lithuania and Slovenia), on the other hand, fare rather well vis-à-vis the SGP rules and have very low government debts.

In this paper, we look at the political factors that may have influenced governments' vigour in fiscal policy conduct. We differentiate NMSs into two groups - those in breach of the SGP (EDP countries) and those complying with it (non EDP countries) - and show different fiscal policy's dynamics in these two groups. We try to separate factors that led successful consolidations in the NMSs. Using detailed data, we illustrate how (in)consistent governments have been in their fiscal plans. We find that governments have regularly rescaled their fiscal programmes submitted to the European Commission (EC). And we do find that the countries breaching the SGP have raised their deficit expectations more frequently and by greater margin than countries complying with the SGP. Those fiscally more profligate governments also tend to get more and more ambitious in their consolidation plans, as they struggle to convince the EU authorities that they will indeed be able to join the European Monetary Union (EMU) in a due time.

${ }^{1}$ The ten countries are Cyprus (CY); Czech Republic (CZ); Estonia (EE); Hungary (HU); Latvia (LV); Lithuania (LT); Malta (MT); Poland (PL); Slovenia (SI); and Slovakia (SK). All became members of the European Union in May 2004 and we will call them throughout the paper New Member States (NMSs). Only Cyprus and Malta had not been members of the socialist, Soviet-run system that collapsed in 1989.

${ }^{2}$ See Schneider and Zápal (2005) for a detailed discussion.

${ }^{3}$ In what follows, when we refer to government, we mean always general government.

${ }^{4}$ All NMSs with respect to SGP are classified as "member states with derogation", which means that those countries are expected to comply with SGP limits for government budget deficit of $3 \%$ GDP and government debt of $60 \%$ of GDP. Although they can not be fined for breaching those limits, they are put under EDP and subsequent intensified fiscal surveillance process and can be prohibited to draw financial resources from EU Cohesion Fund (see European Commission (2004a), pp. 69-72, for details). Awareness of NMSs of the fact that they would be obliged to comply with SGP rules is apparent from Pre-Accession Economic Programmes for year 2001. 
Throughout the paper, we present data from European Commission (2004b) which span till 2006 so clarification is needed as to where predicted values for 2005 and 2006 come from. Current practice is such that all member states are obliged to participate in so called fiscal notification, during which government officials of corresponding country present up-todate facts and data about the development of their budgets to European Commission and EUROSTAT officials. Fiscal notifications take place twice a year in spring and autumn. Based on information submitted from member states, EC prepares forecast for next year or two.

Thus data we use are based on autumn 2004 fiscal notification and therefore for year 2004 present expected values and for years 2005 and 2006 present predictions of EC, based on 2004 autumn information. Although collected according to unified methodology, all the data should be treated with caution since they might possibly be inadequate due to low experience of statistical departments and officers in NMSs or due to methodological ambiguity regarding "nonstandard" operations in NMSs' budgets.

Other source of information we relied on were Pre-Accession Economic Programmes $(\mathrm{PEPs})^{5}$ of NMSs and Convergence Programmes (CoPrs) ${ }^{6}$ of NMSs. Both PEPs and CoPrs lay out plans of governments in NMSs how to consolidate their budget deficits. The existence of various plans allows us to compare fiscal plans and results these plans achieved.

Bearing all the qualifications in mind, we proceed as follows. In the next part, we present very brief discussion of fiscal policy position of the new member states and the "old" fifteen member states of the EU. We illustrate that countries differed in the vigour with which they controlled spending programmes. The third chapter analyses factors of successful consolidations and shows that the EU's pressure has been an important factor.

The fourth chapter is devoted to detailed and comprehensive analysis of the ten NMSs fiscal plans as reflected in their PEPs and CoPrs. Namely, we illustrate how fiscal plans changed over time and how governments regularly missed their fiscal targets.

The fifth chapter summarises our findings on individual countries' fiscal plans and confirms that higher deficits have led consequently to greater revisions and more ambitious plans for future - as opposed to actually delivered - consolidations. Sixth part brings an attempt to quantify "quality" and reform-mindness of the ten NMSs. The seventh chapter briefly concludes the paper and discusses its contributions.

\section{STYLIZED FACTS}

In this section, we briefly present some basic data on the NMSs' fiscal domain. For a more detailed discussion see Schneider and Zápal (2005). As the chart 1a illustrates, the

${ }^{5}$ All NMSs submitted their Pre-Accession Economic Programmes in years 2001, 2002 and 2003. We refer to them as PEP01, PEP02 and PEP03 respectively and add country specific suffix where needed for the sake of clarity (therefore PEP01-CZ refers to PEP of Czech Republic submitted in year 2001). All PEPs presented, among other things, information about fiscal policy in NMSs, its objectives and plans for upcoming period as well as information about structural reforms under way and about those needed or expected.

6 All NMSs submitted one exceptional Convergence Programme in spring 2004 and regular Convergence Programme in autumn 2004. We refer to them as CoPr-spring and CoPr-autumn respectively, again adding country specific suffix when needed (therefore CoPr-spring-CZ refers to Convergence Programme of Czech Republic submitted to EC in spring 2004). CoPrs follow in structure PEPs, though somehow reduced. 
NMSs have differed in the conduct of fiscal policy. Estonia has never had a bigger deficit than $3,7 \%$ in one exceptional year; similarly Slovenia has crossed the $3 \%$ threshold just once in 2000. Other countries have run much more adventurous fiscal policy; the biggest deficit in the Czech Republic and in Slovakia was $12 \%$ of GDP, $10 \%$ in Malta and $9 \%$ in Hungary.

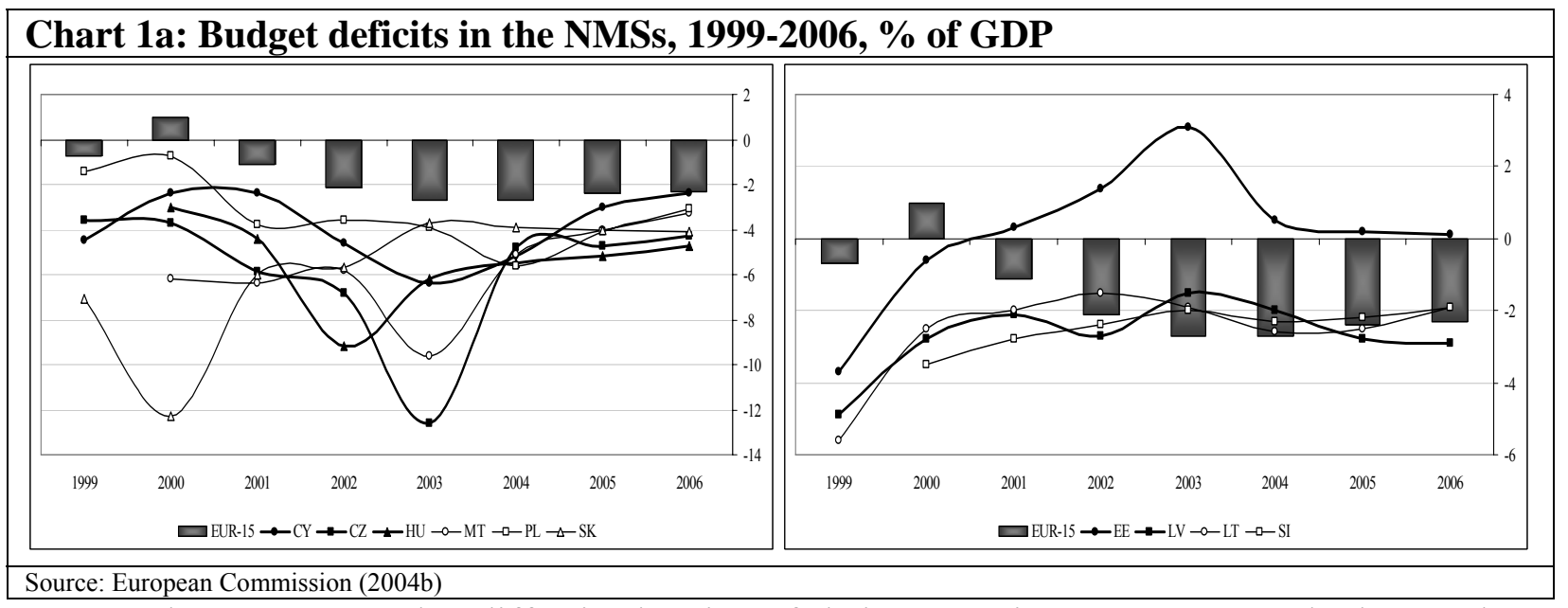

The ten NMSs also differ in the size of their respective governments' budgets. The two groups of countries emerge: small and big governments. The group of small(ish) governments consists of the three Baltic countries (Estonia, Latvia and Lithuania) and Slovakia. The big consists of the remaining six countries: Central European four (Czech Republic, Poland, Hungary and Slovenia) plus two little Mediterranean islands of Cyprus and Malta. While the former group now (in 2004) spends 36-38 \% of their respective GDPs through the government, the latter group is characterised by the government share of $46-52 \%$ in GDP. The gap is thus noticeable and significant - see the chart $1 \mathrm{~b}$.

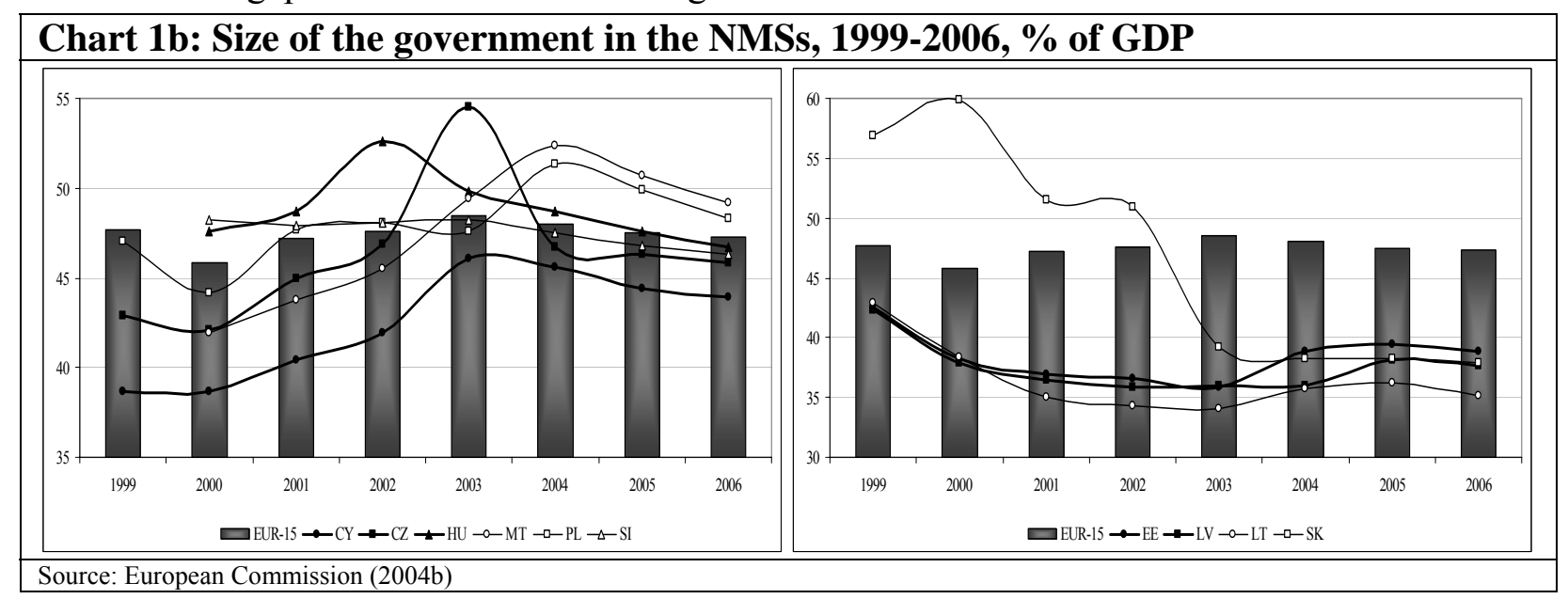

We can thus speculate that there are two groups of countries within the ten NMSs. One relies on higher government expenditures and runs more pronounced budget deficits. This group consists of the Czech Republic, Hungary, Poland, Cyprus and Malta. The second group, represented by the three Baltic republics - Estonia, Latvia and Lithuania - is characterised by lower government budget share in GDP and by low budget deficits. The two countries are somewhat between these two groups: Slovenia has high and stable government expenditures, but it still manages to keep its budget deficit under control. Slovakia, on the other hand, used to be synonymous with unsustainable fiscal policy, but has turned out to be the most fervour 
reformer within the NMSs. It has eliminated a substantial part of government expenditures and limited its budget deficits within the reach of the SGP limit of $3 \%$ of GDP.

Composition of the budget

Alternative way how to approach government budget is to look at the composition of the budget itself. Since there is little variability in this respect over time we include only relevant averages. First table shows composition of the revenues in NMSs.

\begin{tabular}{|c|c|c|c|c|}
\hline \multicolumn{5}{|c|}{$\begin{array}{l}\text { Table 1a: Composition of government budgets in NMSs and EUR-15, } \\
\text { revenue averages for } 1995-2006\end{array}$} \\
\hline & $\begin{array}{c}\text { EDP } \\
\text { countries }\end{array}$ & $\begin{array}{l}\text { non EDP } \\
\text { countries }\end{array}$ & EUR-15 & NMS \\
\hline Indirect taxes & 32,4 & 34,4 & 29,2 & 33,2 \\
\hline of which $\mathrm{VAT}^{7}$ & 17,0 & 21,6 & 14,1 & 18,8 \\
\hline of which Excises & 7,6 & 8,2 & 6,0 & 7,9 \\
\hline Direct taxes & 22,2 & 22,7 & 28,9 & 22,4 \\
\hline of which PIT & 12,2 & 17,7 & 21,3 & 14,4 \\
\hline of which CIT & 8,3 & 4,1 & 5,5 & 6,6 \\
\hline Social contributions & 28,3 & 28,4 & 31,7 & 28,4 \\
\hline \multicolumn{5}{|l|}{ Memo item: } \\
\hline Total revenue, $\%$ of GDP & 42,6 & 38,0 & 46,1 & 40,6 \\
\hline
\end{tabular}

Although EDP and non EDP countries do not differ significantly in the composition of their budgets when divided into indirect taxes, direct taxes and social security contributions, recall that government revenue in EDP countries is approximately $4 \%$ of GDP higher than in non EDP countries which implies that although the composition of the budget revenues is similar, EDP countries burden more heavily on their economies in nominal terms.

Notable differences between EUR-15 and NMSs are to be found in higher reliance on indirect taxation in NMSs given by especially higher reliance on VAT. Higher reliance on indirect taxes might reflect the fact that those taxes are more easily collectible and thus more appropriate source of revenues when tax officials are less skilled, as might be the case in NMSs. On the other hand, EUR-15 countries rely more on direct taxes which form almost third of their budgets.

As regards differences between EDP and non EDP countries, the two groups have very similar revenue shares coming from indirect and direct taxes and from social contribution revenues. Certain differences stem from internal composition of indirect tax revenues where non EDP countries rely more on VAT and from internal composition of direct tax revenues, where EDP countries rely less on PIT and more on CIT revenues when compared to non EDP countries.

Turning now to the expenditure structure of the budgets in NMSs, we also include only average figures for the whole period under consideration.

${ }^{7}$ Abbreviations used for different types of taxes are: VAT for value added tax, CIT for corporate income tax and PIT for personal income tax. 


\begin{tabular}{|c|c|c|c|c|}
\hline \multicolumn{5}{|c|}{$\begin{array}{r}\text { Table 1b: Composition of government budgets in NMS } \\
\text { expenditure averages for 1995-2006 }\end{array}$} \\
\hline & $\begin{array}{c}\text { EDP } \\
\text { countries }\end{array}$ & $\begin{array}{l}\text { non EDP } \\
\text { countries }\end{array}$ & EUR-15 & NMS \\
\hline Employees' remuneration & 22,7 & 28,5 & 22,7 & 25,0 \\
\hline Collective consumption & 22,0 & 24,7 & 17,1 & 23,1 \\
\hline Social transfers in kind & 20,8 & 29,1 & 25,4 & 24,1 \\
\hline Social transfers not in kind & 27,1 & 28,3 & 34,3 & 27,6 \\
\hline Interest & 6,1 & 2,5 & 8,1 & 4,7 \\
\hline Subsidies & 3,9 & 2,7 & 2,7 & 3,4 \\
\hline Investment & 7,7 & 7,5 & 5,0 & 7,6 \\
\hline \multicolumn{5}{|l|}{ Memo item: } \\
\hline Total expenditure, $\%$ of GDP & 47,5 & 39,6 & 48,3 & 44,2 \\
\hline
\end{tabular}

Noteworthy differences between NMSs and EUR-15 include lower expenditure for employees' remuneration, public goods ${ }^{8}$ and public investment in EUR-15 and higher expenditure for redistribution and interests in EUR-15, as compared to NMSs. This reveals the fact, that public sectors in NMSs are more labour intensive. Difference in public investment reflects higher needs for infrastructure projects financing in NMSs and a difference in interest payments reflects lower average indebtness of NMSs.

As regards differences between EDP and non EDP countries, the EDP countries spend relatively less on employees' remuneration, collective consumption and social transfers in kind, but more on subsidies and interest payments. Note also, that the sum of expenditure budget items (excluding public employees' wages, a category that goes "across" other expenditure categories) forms $88 \%$ of budgets in EDP countries and $95 \%$ of budgets in non EDP countries reflecting the fact that often untransparent and non-standard budget operations and expenditure contained in "other" category form almost $12 \%$ of budgets in EDP countries as opposed to $5 \%$ of budgets in non EDP countries.

\section{Dynamics of expenditure categories}

Besides the share of expenditures in GDP, we find it useful to look at the dynamics of public expenditures in the NMSs and the EUR-15 as to assess why six out of ten NMSs currently face EDP.

${ }^{8}$ In what follows, we use basic ESA95 expenditure categories, which are compensation of employees; collective consumption; social transfers in kind; social transfers other than in kind; interest; subsidies; and gross fixed capital formation.

Compensation of employees is self-explanatory category. Collective consumption is defined as expenditure on those services, which are intended simultaneously for all members of the society, i.e. in more economic terms, it is the expenditure on provision of public goods. Social transfers in kind cover those expenditures through which government purchases and provides certain goods for some members of the society, while social transfers other than in kind cover those expenditures through which government grants certain aid to its members in cash. Again, in more economic terms, both types of social transfers can be regarded as redistribution expenditures. Interest are expenditures government pays to cover the costs of public borrowing and subsidies are government unrequited payments, mainly to producers.

Note that collective consumption, both categories of social transfers, subsidies, interest as well as minor "other" category sum up to total current expenditure category we also use. Last ESA95 category is gross fixed capital formation or in more economic terms government investment, which with total current expenditure adds up to almost $100 \%$ of the budget expenditure with rest formed by "other" items. 
The charts $2 \mathrm{a}-2 \mathrm{~d}$ presents the results of our exercise. The charts reveal several interesting patterns. First regards employees' compensation which grew in the EUR-15 by approximately $1 \%$ annually in real terms. In the NMSs employees' remuneration rose considerably faster, especially in the period since 2001 through 2003. Chart 2a suggests that the EDP countries have relaxed its wage policies earlier (remuneration jumped by almost 10 $\%$ in 2002), but the non-EDP countries followed with a healthy increase in remuneration of 8 $\%$ in 2003.

Similar story applies for other two expenditure items, collective consumption and for aggregation of both types of social transfers: the NMSs have witnessed much more volatile developments than the EUR-15, but on average, both expenditure items grew faster in the NMSs than in the EUR-15. Faster growth has also been slightly higher in EDP than in non EDP countries, suggesting that policy-makers in EDP countries followed more relaxed policies through the beginning of this decade.

Last major expenditure item is the growth of gross fixed capital formation. Chart $2 \mathrm{~d}$ illustrates that while investment grew healthily both in the EDP and non EDP countries, the non EDP countries feel now confident to envisage a rapid acceleration of public investment, while the EDP countries plan much cautiously.

Taken charts $2 \mathrm{a}-2 \mathrm{~d}$ together, they point to a more lax expenditure control in the EDP countries which has contributed to their non-compliance with the SGP. Especially in case of employees' remuneration and both types of social transfers, real growth rates in EDP countries exceeded those in non EDP countries throughout the outset of this century.

Development of growth rates in EDP countries also reveals something what could be called a SGP induced effect, which is clear when comparing real growth rates of expenditure items in years 2003 and 2004. Data indicate that all the EDP countries

\section{Chart 2a: Real growth of employees' compensation}

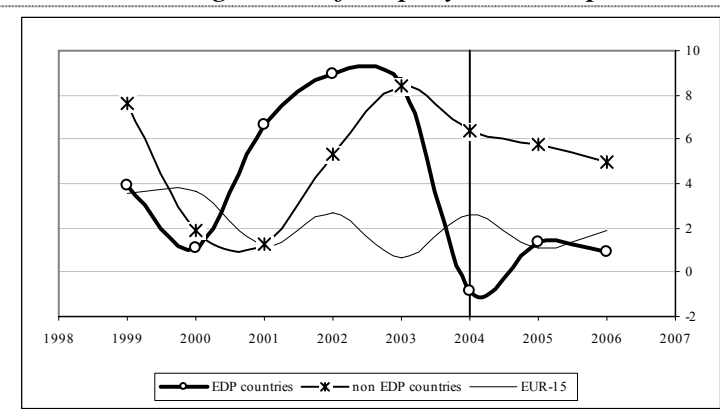

Chart 2b: Real growth of collective consumption

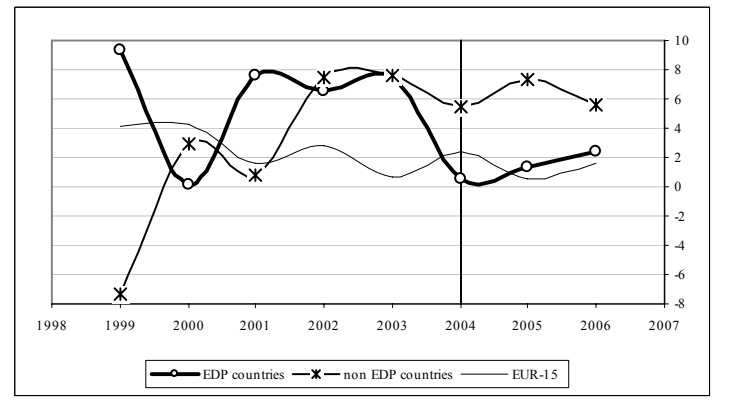

Chart 2c: Real growth of social transfers (both types)

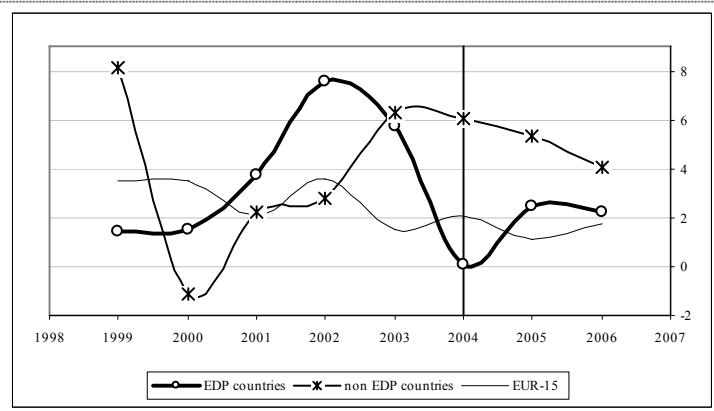

Chart 2d: Real growth of gross fixed capital formation

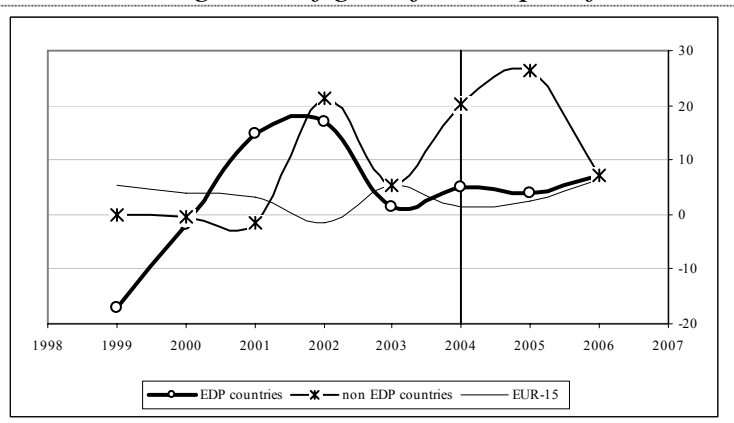

Source: European Commission (2004b); Authors' calculations planned a massive slowdown of the expenditure growth, most likely in order to comply with 
SGP. ${ }^{9}$ The non-EDP countries, on the other hand, have enjoyed the luxury of gradual slowdown of real growth rates of the expenditure items included without significant rush. It remains to be explained why the EDP countries did not react earlier and more orderly to raising fiscal difficulties.

To sum up this section, EDP countries are those with significantly higher government involvement in the economy as measured by the share of revenues and expenditures to GDP. The EDP countries have aggravated their budget woes by allowing a faster growth of employees' remuneration and both types of social transfers in the past. This higher growth rates have reversed lately, reflecting effort of the EDP countries to cut budget deficits. However, authorities in the EDP countries had waited until the very last moment before any action in this respect and then applying sudden stop strategy. The non EDP countries could afford a more gradual reduction in expenditures growth rates. Data also reveal that while major part of consolidation effort in EDP countries falls on employees' remunerations and social transfers of both kinds, the EDP countries have also reined in their investment expenditures, limiting long-term growth prospects in order to comply with European fiscal rules.

Therefore, current problems of EDP countries with SGP seem to be given by the mix of their larger governments' involvement in the economy, by higher rigidity of their budgets, and by the fact that policy-makers in those countries has recently allowed for escalation of politically sensitive expenditure items.

\section{POLITICAL ECONOMICS OF SUCCESSFUL CONSOLIDATIONS}

Given the NMSs' apparent difficulties in consolidating budget deficits, we analysed factors that contributed to successful fiscal consolidations. One possible important set of factors are exogenous to fiscal policy: strong economic growth lowers the probability of introduction of consolidation since it lowers budget deficit irrespective of governments' actions while high or growing public debt levels increase the probability of introduction of consolidation. Outside factors can also be relevant, for example positive economic growth of main trading partners can support domestic economic growth and thus lower the probability of consolidation or peer pressure of consolidating neighbouring countries can increase the probability of consolidation.

Second important set of factors are given more by internal political economy concerns. In this respect elections can postpone introduction of consolidation plans. We were also interested whether initiation of EDP would show to increase the probability of introduction of consolidation in NMSs.

In accordance with the literature, we define period of fiscal consolidation as a period in which government primary budget deficit to GDP ratio (budget deficit less interest on public debt) improved by more than $1 \%$ of GDP in the first year and improved in second and

\footnotetext{
${ }^{9}$ The data for 2004 in this paper are based on ,estimates“, i.e. they are not final yet and are subject to revisions.
} 
later years. ${ }^{10}$ Consolidation is said to last, until government primary budget deficit to GDP is being reduced. ${ }^{11}$

Based on our definition of consolidation, we created dummy variable with unity values in years of consolidation periods and run a probit model in order to see how different economic and political economy factors have contributed to consolidations in NMSs. For internal economic exogenous variables, we include growth position of domestic economy captured by output gap, GAP and government debt, DEBT. For external factors, we include average budget position of EUR-15, FISC_E and growth position of EUR-15 captured by output gap, GAP_E. For political economy factors, we include two dummies. First is dummy for EDP initiation with given NMS, EDP and second is a dummy which takes on value of unity in election years, EL (election year is defined as a year of general parliamentary elections when it took place in the second half of the year and year preceding when elections took place in the first half of the year). Results are given in the table 2.

Table 2: Probit analysis of consolidations in NMSs, 1995-2006

\begin{tabular}{|c|c|c|}
\hline \multicolumn{3}{|c|}{$\begin{array}{l}\text { Dependent variable: Consolidations defined using } \\
\text { deficit (left column) or using primary budget deficit (right column) }\end{array}$} \\
\hline \multirow[t]{2}{*}{$\mathrm{C}$} & $-3,09^{* * *}$ & $-3,69^{* * *}$ \\
\hline & $(0,88)$ & $(1,01)$ \\
\hline \multirow[t]{2}{*}{ GAP } & $-0,32^{* * *}$ & $-0,21^{* *}$ \\
\hline & $(0,09)$ & $(0,10)$ \\
\hline \multirow[t]{2}{*}{ DEBT } & $0,04^{* * *}$ & $0,04^{* * *}$ \\
\hline & $(0,01)$ & $(0,01)$ \\
\hline \multirow[t]{2}{*}{ FISC_E } & 0,05 & 0,06 \\
\hline & $(0,30)$ & $(0,34)$ \\
\hline \multirow[t]{2}{*}{ GAP_E } & 0,50 & 0,59 \\
\hline & $(0,45)$ & $(0,51)$ \\
\hline \multirow[t]{2}{*}{ EDP } & $1,79^{* * *}$ & $2,49^{* * *}$ \\
\hline & $(0,46)$ & $(0,55)$ \\
\hline \multirow[t]{2}{*}{ EL } & 0,08 & $-0,07$ \\
\hline & $(0,35)$ & $(0,38)$ \\
\hline $\mathrm{R}^{2}$ & 0,32 & 0,36 \\
\hline \multicolumn{3}{|c|}{$\begin{array}{l}\text { Note: Estimates for NMSs for } 1995 \text { through 2006. Dependent variable dummy taking on unity in year } \\
\text { when relevant country underwent fiscal consolidation. GAP is deference between actual and potential } \\
\text { output. DEBT is public debt to GDP ratio. FISC_E is average fiscal position of EUR-15 (surplus with } \\
\text { "+" sign) and GAP_E is average output gap of EUR-15. EDP is dummy which takes on value of unity } \\
\text { in year when relevant country was under EDP. EL is dummy taking on value of unity in elections years } \\
\text { (definition used in the text). Data from European Commission (2004b) and AMECO database. All } \\
\text { economic data in levels and lagged one year. Standard errors in parentheses. *** significant on } 1 \% \text {, } \\
* * \text { significant on } 5 \% \text { and * significant on } 10 \% \text {. }\end{array}$} \\
\hline
\end{tabular}

${ }^{10}$ We do not use definition of fiscal consolidation of Hagen, Hallett and Strauch (2001) because it is too restrictive and thus we would be able to identify only very few periods of fiscal consolidation in our data sample. Also, we do not use cyclically adjusted budget data because those are not readily available. See also Schneider and Zápal (2005) for analysis of composition of consolidations in NMSs.

Further, we analysed the National Accounts for any consolidation period. The NA data which differ somehow in methodology from ESA95 data we use here and a gap would indicate possibility of creative accounting by national authorities being our major concern. Problem with National Accounts is that they differ in structure and it is not easy to extract general government expenditure without immediately crossing into ESA95 data. Main reason for this is that, just as National Account, ESA95 relies as much as possible on economically more meaningful accrual principle. Despite difficulties, we have found no considerable difference between development of fiscal data in National Accounts as opposed to ESA95 data.

${ }^{11}$ Consolidation identified according to our definition are CY 2000-2001, 2004-2006; CZ 1996-1997; 2004-2006; EE 2000-2003; LV 1996-1997, 2000-2001; LT 2000-2002; HU 2003-2004; MT 2004-2006; PL 2005-2006. 
Probit model we estimated reveals that domestic economic conditions play a key role in that they have either positive or negative effect on probability of consolidation introduction. Estimated coefficients show, that growth of domestic economy has considerable, statistically significant and negative effect on probability of consolidation initiation. Also statistically significant although not notable effect has public debt level to GDP ratio.

On the other hand, outside conditions we tried to capture in our model by inclusion of EUR-15 average output gap and fiscal stance do not have significant effect on probability of consolidation introduction. Similarly, elections do not have any effect on the probability of consolidation.

Estimated coefficients of probit model also show that most pronounced, statistically significant and positive effect on consolidations had the initiation of EDP with NMSs. This finding suggests that the SGP and the EU's procedures have essential disciplining effect on policy-makers in NMSs. As a corollary to this finding, the model also shows that policymakers waited until the last moment before EU accession before tackling the problem of growing budget deficits and also that there is an outside disciplining force needed in order to induce the very same policy-makers in NMSs to behave responsibly.

\section{FISCAL PLANNING BY THE NMSS}

In this section we present brief description of fiscal policy in NMSs based on their PEPs and CoPrs. ${ }^{12} \mathrm{We}$ focus on major trends and influences on fiscal policy and try to track down key factors which influenced development of fiscal position in NMSs prior to their EU accession.

As regard timing of submission of the mentioned documents, first set of PEPs from year 2001 was submitted in two rounds. First round (CY, CZ, EE, HU, LV) was submitted in May 2001 and second round (LT, MT, PL, SI, SK) in October 2001. Second and third set of PEPs was submitted by all NMSs jointly in August 2002 and 2003 respectively. All spring CoPrs were submitted in May 2004 and most of autumn CoPrs in November or December 2004 with the exception of LT and SI who submitted their second CoPrs in January 2005.

For official evaluation of ambitiousness and fulfilment of plans outlined in PEP01 through PEP03 see European Commission (2002a), European Commission (2002b) and European Commission (2003a) respectively. For evaluation of CoPr-spring and CoPrautumns, decisions about EDP initiation and recommendations of explicit steps needed to bring budget deficits under control by EC, see its website. We also do not tackle issue of link of all submitted documents to national budgets of NMSs for which see discussion in Ylaoutinen (2004).

To see how plans of NMSs changed during pre-accession period and how they compare to reality, we went through all the PEPs and CoPrs of NMSs and put outlined or planned trajectory of budget deficits into one single graph we present for each country.

${ }^{12}$ The longer description of fiscal policy of each NMS appeared in original version of the paper. Since each NMS has been devoted roughly two pages of text, we present here only short version. However, longer version is available upon request from the authors. 
Fiscal policy in Cyprus in period under consideration has been influenced by two key factors. First one is negative development after September $21^{\text {st }}, 2001$ which hit small and touristbased Cypriot economy and had negative impact on government budget position. Second key factor has been repeated effort of government to consolidate its budget after loose fiscal policies in second half of 1990's. Due to repeated misimplementation of envisioned consolidation measures, inability to cope with increasing

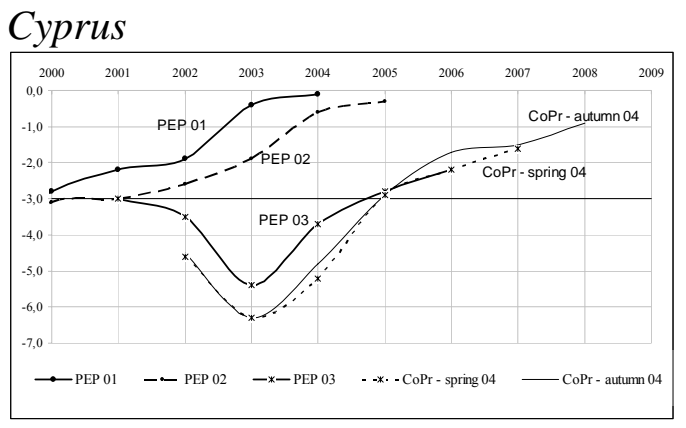

Note: PEP 01 data based on GFS methodology. defence, agricultural, old-age related or public employment spending, budget position kept deteriorating throughout the whole pre-accession period. The key reason behind this development has been lack of political will which resulted in apparent postponement of consolidation measures. As a result, Cyprus has been put under EDP following its EU entry.

Czech Republic's public finance position deteriorated from original position at the beginning of the decade mainly due to continuing pressure of social related expenditure and due to one-off transformation related costs. As a result, Czech government in 2003 introduced consolidation programme consisting of mix of revenue increasing and expenditure decreasing measures. However, impact of consolidation fell short of originally expected one due to slow implementation, especially of expenditure related

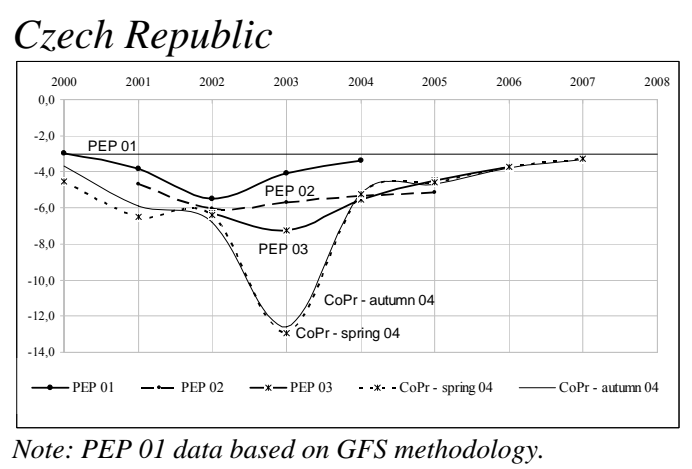
steps. In future and most importantly, yet unreformed PAYG pension system combined with quickly ageing population will exert further pressure on Czech public finance. This will further complicate position within EDP into which Czech Republic has been put after its EU entry. $^{13}$

Estonia entered the new millennium with favourable budget position despite negative impact of Russian crisis. The country kept its strong reform focus, reforming its health and pension systems. Despite obvious short-term costs associated with those reforms, Estonia managed to keep its budget roughly in balance, with the exception of 2003 when a strong economic growth delivered a budgetary surplus. Estonian officials repeatedly stress balanced budget goal in all the

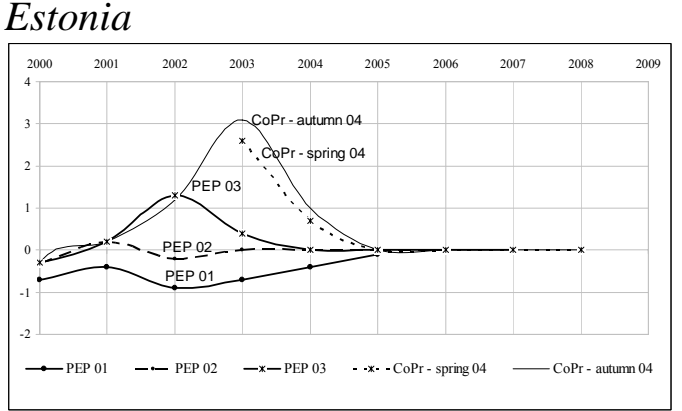
documents submitted and seem to be aware of need to run responsible fiscal policy in order

${ }^{13}$ Due to methodological treatment of government guarantees and their re-classification, government budget deficit for year 2003 has been recalculated in 2004 and reached above $12 \%$ of GDP. Without the methodological change and subsequent recalculation, government budget deficit would stand at 5,6\% of GDP against which improvement should be measured. 
not to threaten external macroeconomic balance and conflict with by non-flexible exchange arrangement restricted monetary policy.

Hungary repeatedly revised its budget plans and postponed bringing budget deficit under $3 \%$ of GDP required by SGP. Among major reasons cited, unexpectedly high pension expenditure, public employees' wages, health related or social benefit expenditure repeatedly appear along with unexpected development of government debt servicing costs stemming from increasing interest rates required to protect pegged exchange rate. Despite several expenditure

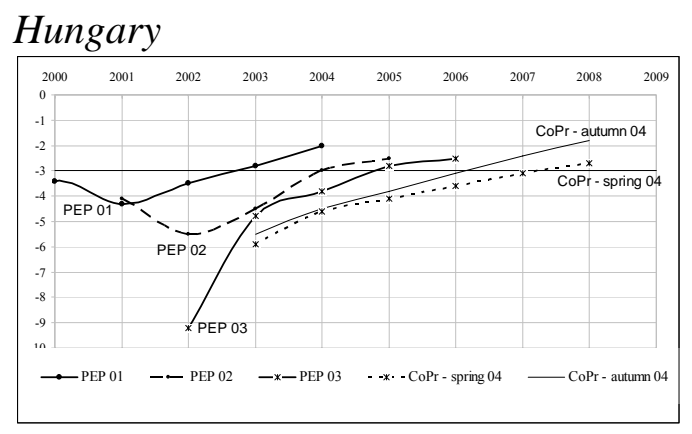
reducing steps implemented by Hungarian government during fiscal years of 2003 and 2004, Hungarian budget deficit exceeded $3 \%$ of GDP by the date of EU entry with subsequent EDP initiation.

Latvian authorities envisioned gradual reduction of its already favourable budget deficit towards the balanced position at the time of PEP01 submission. Outlined plans have been repeatedly revised partly as a result of increase of defence, health or education expenditure and partly as a result of repeated reduction in several tax rates with resulting lower budget revenue. Despite this development, Latvia managed to keep its deficit below 3\% SGP benchmark, being supported by strong economic growth. At the same time, several

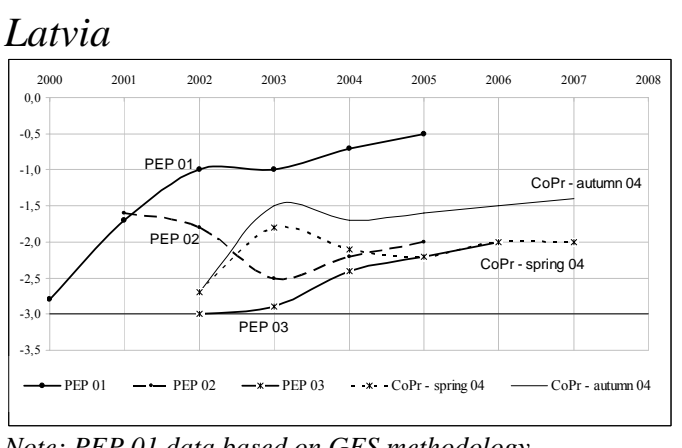

Note: PEP 01 data based on GFS methodology. ongoing reforms, health and pension system reforms were implementedbeing probably the most important ones without throwing budget into higher deficits. More or less constant budget deficit combined with strong economic growth rises concerns about pro-cyclicality of Latvian fiscal policy and future development should strong economic performance eventually slow down.

Developments in Lithuania closely resemble those in Latvia. Originally envisioned reduction of budget deficit towards zero values was overridden by several tax rates reductions and list of expenditure increasing measures linked to ongoing health and pension systems reforms on the one hand and to increases in public employees' enumeration, public investment or social transfers on the other. Due to strong economic growth Lithuania has kept its budget under $3 \%$ SGP benchmark, but there are raising concerns about

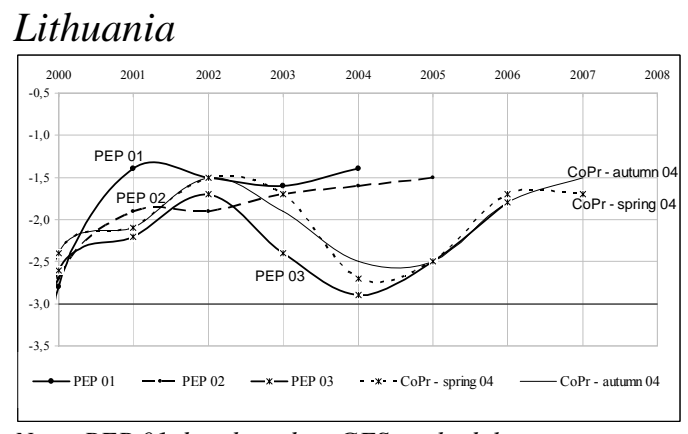
Note: PEP 01 data based on GFS methodology. external macroeconomic imbalance, high current account deficit and restricted exchange rate arrangement. 
Malta entered this decade with considerable budget deficit exceeding $6 \%$ of GDP. However, as described in PEP01, this still represented an improvement compared to deficits experienced throughout second half of 1990's. Consolidation programme launched by Maltese government aimed to bring budget deficit to more reasonable position has been only partly successful. Partly due to developments after September $21^{\text {st }}, 2001$ and partly as a result of

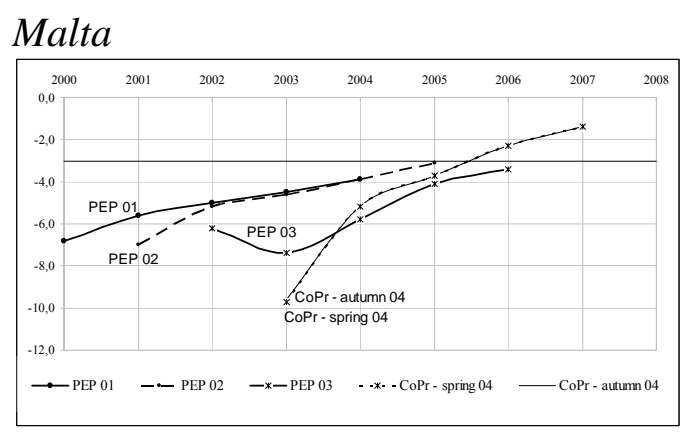
ongoing increases of expenditure on public employees' wage bill, old-pensions expenditure and several one-off expenses on construction of new hospital or restructuring of publicly held Malta Shipyard Company, Malta has been unable to comply with SGP by the date of EU accession. Whether implementation of list of exhaustive measures intended to bring budget deficit in compliance with SGP outlined in CoPr-autumn eventually takes place and results in improvement of Maltese budget position remains yet open question.

Polish authorities expected further deterioration of budget deficit by the date of PEP01 submission citing increasing inflation-indexed social benefits and public wages as well as planned reduction of CIT as a main reason and outlining public finance reform intended to tackle those problems. Inability to implement reform measures, further reduction of tax rates and unexpectedly high pension reform related costs resulted in revision of budget deficit trajectory and launch of EDP with Poland by the date of EU entry. In

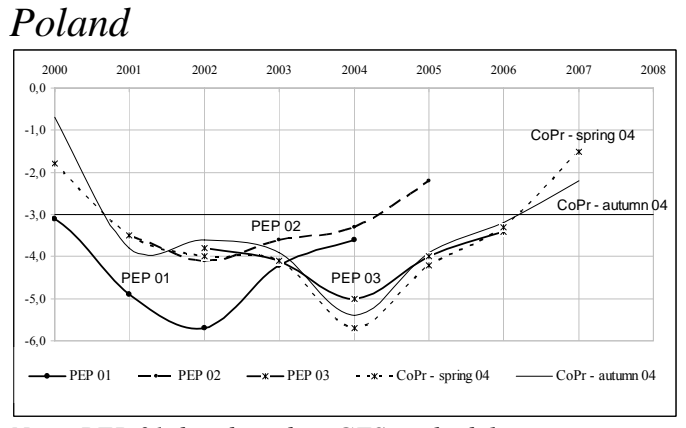
Note: PEP 01 data based on GFS methodology. expectation of such development, CoPr-spring outlines comprehensive and explicit set of public finance reform measures aiming to bring Poland in compliance with SPG.

Slovenia has kept its budget deficit within $3 \%$ SGP benchmark for the whole preaccession period, displaying mild tendency to revise its plans. Reasons behind deterioration of budget position can be found in growth of public employees' wage bill and growth of indexed social benefits and transfers. To cope with those problems, Slovenia government negotiated new social agreement for the period 2003 through 2005 which, among others, included new rules for

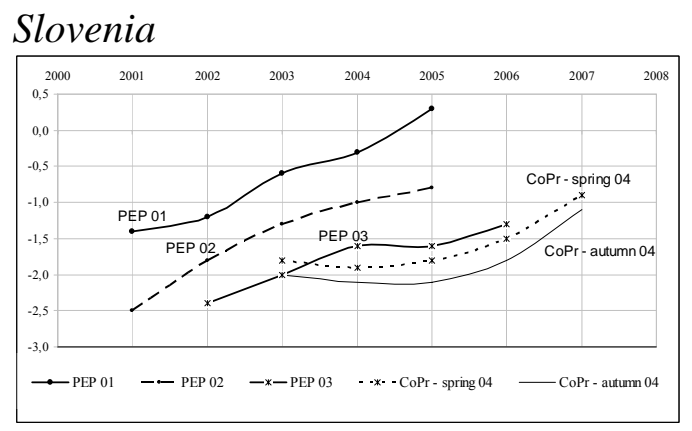
public sector wage indexation. Similar attempt in direction of de-indexation and rationalization of system of social transfers has been made. On the other hand, reduction of PIT rates and change in corporate taxation code put budget under further pressure. Despite such development, Slovenia remains within safe distance of SGP $3 \%$ benchmark. 
Slovakia experienced considerably high budget deficits throughout the beginning of the decade, mainly as a result of transformation related costs, rising pension and health care expenditure and short-fall of tax revenue. Yet, since 2003 Slovakia repeatedly displays strong reform efforts. Speedy reform of its pension system, ongoing decentralization of public finance, health reform, labour code reform, implementation of programme budgeting or introduction of comprehensive flat-tax schedule is worth noticing.

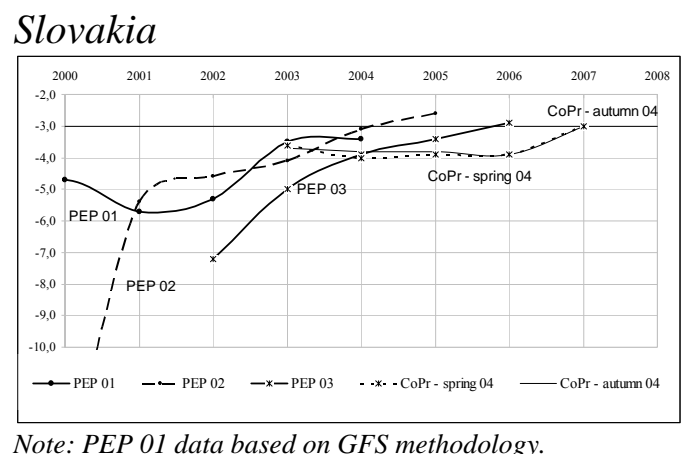
Short-term related costs of some of those steps then lie behind apparent stability of budget deficit on SGP violating $4 \%$ of GDP level.

\section{MERIT OF FISCAL PLANS}

In the previous chapter we identified tendency of NMSs to revise their budget deficits from submission of one document to another and in most cases this revision has been an upward one. Those repeated revisions provide a unique research opportunity to analyse government fiscal policy's consistency.

This chapter draws on Strauch, Hallerberg and Hagen (2004) who look at revisions of budget deficit trajectories from CoPrs of EUR-15. We took budget deficit data from each PEP and CoPr of every NMS and computed average revision between two consecutive documents taking into account only those years, for which budget deficit has been included in both documents. This average revision from one document to another then allowed us to compute average revision of budget deficit in various NMSs countries and group of countries.

First, we tested whether EDP countries revised their budgets more than non EDP countries. The second aspect we focused on was an impact of general parliamentary elections on the revisions. Combining these two criteria, we analysed whether elections' impact differs in EDP and non EDP countries. Lastly, we examined whether there was any difference between different "categories" of official governments' documents, i.e. between pre-accession economic plans (PEPs) and members' convergence programmes (CoPrs) and whether this difference is the same for EDP and non EDP countries. The following table summarises our results and brings several interesting insights. 


\begin{tabular}{|c|c|c|c|}
\hline \multicolumn{4}{|c|}{ Table 3: Average revision of expected budget deficit } \\
\hline EDP countries & 0,55 & $\begin{array}{l}\text { Election years in EDP } \\
\text { countries }\end{array}$ & 1,43 \\
\hline Non EDP countries & 0,10 & $\begin{array}{l}\text { Non election years in EDP } \\
\text { countries }\end{array}$ & 0,38 \\
\hline Difference & $0,45^{* * *}$ & Difference & $1,05^{* * *}$ \\
\hline Election years & 0,72 & $\begin{array}{l}\text { Election years in non EDP } \\
\text { countries }\end{array}$ & 0,05 \\
\hline Non election years & 0,28 & $\begin{array}{l}\text { Non election years in non EDP } \\
\text { countries }\end{array}$ & 0,12 \\
\hline Difference & $0,44^{* *}$ & Difference & $-0,07$ \\
\hline \multicolumn{2}{|c|}{ Between PEP01 and PEP02 } & \multicolumn{2}{|c|}{ Between PEP03 and CoPr-spring } \\
\hline EDP countries & 0,48 & EDP countries & 0,56 \\
\hline Non EDP countries & 0,43 & Non EDP countries & $-0,28$ \\
\hline Difference & 0,06 & Difference & 0,85 \\
\hline \multicolumn{2}{|c|}{ Between PEP02 and PEP03 } & \multicolumn{2}{|c|}{ Between CoPr-spring and CoPr-autumn } \\
\hline EDP countries & 1,33 & EDP countries & $-0,15$ \\
\hline Non EDP countries & 0,33 & Non EDP countries & $-0,10$ \\
\hline Difference & 1,00 & Difference & $-0,05$ \\
\hline
\end{tabular}

The table reveals significantly higher tendency for budget deficit revisions in EDP countries. Revisions also tend to be higher in cases when general parliamentary elections took place between dates of submission of two consecutive documents. What is, however, striking is the difference between the EDP and non EDP countries in this respect: elections seem to play no role in the non-EDP countries' revisions, while the EDP countries hike their expected deficits massively after an election, as a new government puts all the blame on the previous administration.

Revisions of budget deficits between different pairs of document also differ significantly. EDP countries revised their budget deficits by the largest amount between the submission of PEP02 and PEP03 and somehow less between submission of PEP01 and PEP02 and between the submission of PEP03 and CoPr-spring. Between CoPr-spring and CoPr-autumn then EDP countries revised their budget deficits downward, mainly as a result of additional measures that were taken in order to ensure that trajectory of budget deficit outlined in CoPr-spring and which forms binding limit in the EDP framework. This suggests that budgets of EDP countries are more prone to diverge from predicted values or that policymakers in EDP countries are slower or less dedicated to take corrective measures in case of such divergence. ${ }^{14}$ Thus, one may speculate that the EU membership has increased quality and consistency of the EDP countries' fiscal planning.

On the other hand, non EDP countries revised their budget deficits upward between submission of PEP01 and PEP02 and between submission of PEP02 and PEP03 and downward between the submission of PEP03 and CoPr-spring and between the submission of CoPr-spring and CoPr-autumn, without any apparent need to comply with SGP. Again, one may conjecture that these countries did not need additional "peer pressure" from the EU.

${ }^{14}$ In an accompanying paper (Schneider and Zápal (2005)), we found that EDP countries have significantly higher share of open-ended expenditure to GDP, i.e. higher share of government expenditure which is beyond direct control of politicians which can render budgets in EDP countries more susceptible to unexpected surprises. 
The table 4 shows that the EDP governments were making their planned reductions of budget deficit more ambitious at the same time as they were failing to bring their existing deficits under control. The table shows average changes of budget deficit between the time of submission of relevant document and time four years ahead, again averaging over EDP and non EDP countries and different documents.

\begin{tabular}{|c|c|c|c|}
\hline \multicolumn{4}{|c|}{$\begin{array}{c}\text { Table 4: Envisioned reduction of government } \\
\text { budget deficit four years ahead }\end{array}$} \\
\hline & EDP countries & non EDP countries & Difference \\
\hline PEP01 & 1,70 & 0,53 & 1,17 \\
\hline $\begin{array}{l}\text { PEP02 } \\
\end{array}$ & 2,03 & 0,35 & 1,68 \\
\hline PEP03 & 2,63 & 0,45 & 2,18 \\
\hline CoPr-spring & 2,68 & 0,35 & 2,33 \\
\hline CoPr-autumn & 2,52 & 0,33 & 2,19 \\
\hline \multicolumn{4}{|c|}{$\begin{array}{l}\text { Note: Envisioned reduction of government budget deficit to GDP ratio in } \\
\text { four years period from the year of submission of relevant document } \\
\text { *** significant on } 1 \%, * * \text { significant on } 5 \% \text { and } * \text { significant on } 10 \% \text {. } \\
\text { Source: Authors' calculations based on PEPs CoPrs of NMSs }\end{array}$} \\
\hline
\end{tabular}

Non EDP countries on average aimed to reduce their budget deficit in four year period from the year of submission of different documents by $0,4 \%$ of GDP and there is no significant change over time. On the other hand, tendency of policy-makers in EDP countries to envision faster consolidation had been increasing from the submission of PEP01 to submission of CoPr-spring and declined slightly in CoPr-autumn. Although the differences in envisioned speeds of consolidations in EDP countries are small, data show that policy-makers in those countries postponed unpopular consolidations solving the problem partly by outlined faster consolidations in future.

Based on data in last two tables, we can construct average trajectory of budget deficit in EDP and non EDP countries. Taking average budget deficit in year 2001 for EDP and non EDP countries as the basis, we can construct starting point of each curve by adding average revision of budget deficit and determine its slope from envisioned budget deficit reduction.

Non EDP countries remained for the period 2001 through 2004 below SGP $3 \%$ of GDP benchmark, although they revised their budget deficits as well.. At the same time, the slope of budget trajectoriy for the average non EDP country does not change over time - see chart 3a.

On the other hand, EDP countries were unable to reach the SGP limit due to their considerable revisions of budget

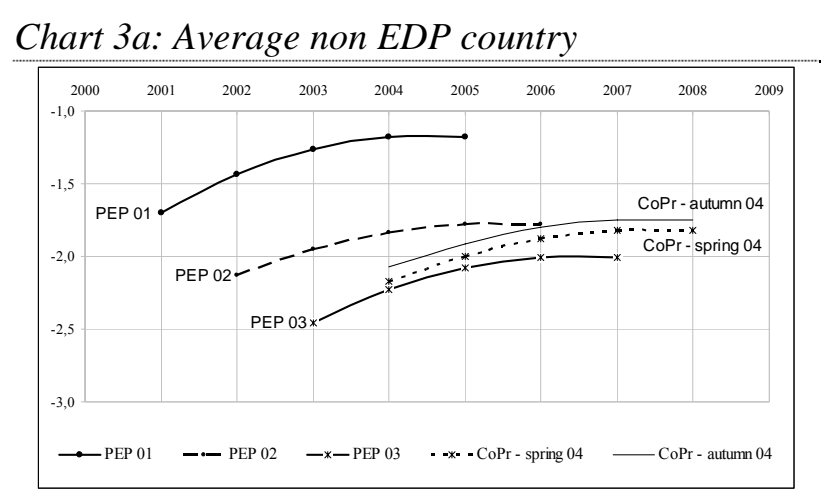

Chart 3b: Average EDP country

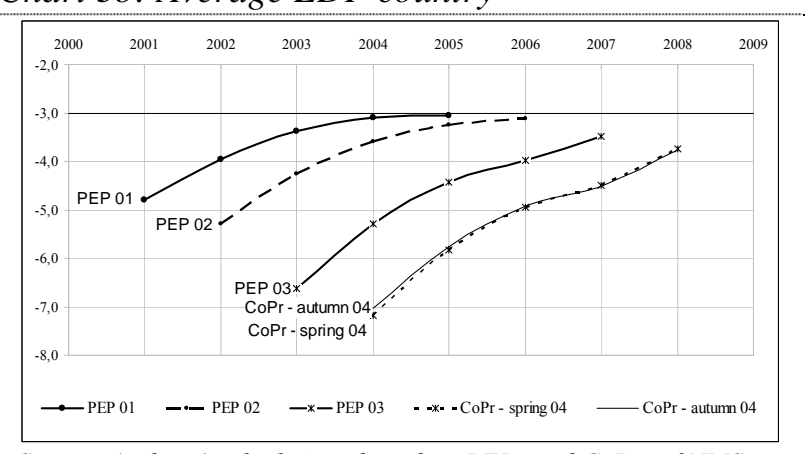

Source: Authors' calculations based on PEPs and CoPrs of NMSs 
deficits. They thus pushed the trajectory forward in time. At the same time, their planed consolidations were getting ever more ambitious, i.e. increasing the slope of the consolidation trajectory - see chart $3 \mathrm{~b}$. This steepening indicates that the EDP countries' governments target ever more ambitious reforms as their starting positions keeps worsening. Thus, governments behave as in denial and keep promising improvement, ignoring their mis-performance in the past.

One possible objection to our findings that EDP countries revise their budget deficit plans more often due rather to political economy concerns is that such a development might be driven by other factors. For example, higher tendency of EDP countries to revise their plans might be given by repetitive revision of macroeconomic predictions on which budget plans are based. If this were true, then our finding about higher tendency of EDP countries to revise their budget plans would reflect more quality of macroeconomic forecasting in EDP countries rather than political economy considerations.

We checked this hypothesis by taking average budget deficit revision from between each pair of documents in each NMS and regressed it on set of factors, most importantly on average revision of predicted growth rate between the same pair of documents, GDP_R. ${ }^{15}$ Both measures of revisions are defined such that higher number means either revision of government budget deficit towards higher surplus (lower deficit) or revision of growth prospect towards higher growth rate.

In our regression we included three political economy variables. First is the dummy which takes on value of unity when parliamentary elections took place between the submissions of relevant documents, EL. Second political economy variable is index of power of finance minister (MF) during budget preparation and implementation, $\mathrm{P}_{-}$MF, defined such that higher number captures more powerful finance minister. Values of $\mathrm{P}_{-} \mathrm{MF}$ were taken from Gregor (2004). Last political economy variable is interaction term between cabinet cohesion index, $\mathrm{COH}$, constructed according to Roubini and Sachs (1989) methodology by Gregor (2004) with the growth prospect revision. Because index of cabinet cohesion as originally defined by Roubini and Sachs (1989) takes on lower values with greater cohesion, we use negative value of cohesion index based on the idea that higher expected growth (higher GDP_R) as well higher cabinet cohesion leads to improvement of budget prospects. Alternatively, lower expected growth as well as more fragmented governments might together lead to worsening of the budget picture given inability of fragmented governments in case of change in macroeconomic prospects.

Last variable we include is the change in ratio of current account deficit to GDP, CA, so as to capture the external macroeconomic position of each NMSs. We defined our CA variable thus that higher and positive values denote improvement in current account, or in other words, improvement in external macroeconomic imbalance. Rationale for inclusion of change in current account deficit is that government might react to growing macroeconomic imbalance by refraining from increase of budget deficit not to worsen such development.

${ }^{15}$ Along the predicted path of government budget deficit, each PEP and CoPr obligatorily includes macroeconomic prediction on which the budget prediction is based. 
Given three PEP and two CoPr submissions, we have four measures of revision for budget balance and growth for each NMS. We organized the data to the panel and present estimated coefficients in the next table.

\begin{tabular}{|c|c|c|c|}
\hline \multicolumn{4}{|c|}{ Table 5: Determining factors of budget revisions } \\
\hline & All NMS & EDP countries & non EDP countries \\
\hline \multirow[t]{2}{*}{$\mathrm{C}$} & $-0,90^{* *}$ & $-0,43$ & $-2,77^{* * *}$ \\
\hline & $(0,42)$ & $(0,54)$ & $(0,95)$ \\
\hline \multirow[t]{2}{*}{ GDP_R } & $2,67^{* * *}$ & $3,57^{* * *}$ & 0,34 \\
\hline & $(0,75)$ & $(1,31)$ & $(0,80)$ \\
\hline \multirow[t]{2}{*}{ EL } & $-0,52^{* *}$ & $-0,82^{*}$ & $-0,17$ \\
\hline & $(0,24)$ & $(0,45)$ & $(0,25)$ \\
\hline \multirow{2}{*}{$P_{-} \mathrm{MF}$} & $0,12^{*}$ & 0,03 & $0,34^{* * *}$ \\
\hline & $(0,06)$ & $(0,10)$ & $(0,12)$ \\
\hline \multirow[t]{2}{*}{$\mathrm{COH} * \mathrm{GDP} \_\mathrm{R}$} & $1,05^{* * *}$ & $1,43^{* *}$ & 0,19 \\
\hline & $(0,31)$ & $(0,62)$ & $(0,32)$ \\
\hline \multirow[t]{2}{*}{$\mathrm{CA}$} & $-0,04$ & 0,03 & $-0,12^{* * *}$ \\
\hline & $(0,04)$ & $(0,06)$ & $(0,04)$ \\
\hline $\mathrm{R}^{2}$ & 0,40 & 0,48 & 0,59 \\
\hline \multicolumn{4}{|c|}{$\begin{array}{l}\text { Note: Dependent variable is average budget revision between two documents presented to EU (positive } \\
\text { values for better budget position). GDP_R is average change in predicted growth rate between the } \\
\text { same two documents (positive values for better growth prospects). EL is dummy variable with values of } \\
\text { unity when general parliamentary elections took place between the submissions of documents. P_MF is } \\
\text { index of power of finance minister taken from Gregor (2004) (higher values signify stronger MF). COH } \\
\text { is index of government fractionalization taken from Gregor (2004) (higher values signify cohesive } \\
\text { governments). CA is change in current account deficit (positive values for improvement). Random } \\
\text { effect panel data estimation (unambiguously implied by Hausman statistics on standard levels of } \\
\text { significance). Standard errors in parentheses. *** significant on } 1 \% \text {, ** significant on } 5 \% \text { and * } \\
\text { significant on } 10 \% \text {. }\end{array}$} \\
\hline
\end{tabular}

Our findings suggest that both economic and political economy factors are behind NMSs' budget plans revisions. As expected, improvement in growth prospects brings about also improvement in budget plans. Among political economy factors which cause improvement in planed budget position are more powerful MF and (combined with improved growth prospect) also less fragmented governments. On the other hand, occurrence of elections has negative effect on planed fiscal position. In our basic specification, estimated coefficient on change in current account deficit turned out to be insignificant and also negligible in its effect.

Subsequently, we split our sample into EDP and non EDP countries. Growth-induced revisions seem to be more frequent in EDP countries as opposed to non EDP countries, for which coefficient on growth revision turned insignificant. According to our previous findings, negative election influence on budget plans is the issue of EDP countries only where also political fragmentation might be of concern. On the other hand, power of finance minister turns out to be significant in non EDP countries along with change of current account deficit for which negative estimated coefficient suggests that improvement in external macroeconomic balance is accompanied with loosening fiscal position.

An unanswered question remains whether the tendency to revise the budget deficit trajectory will remain, especially in EDP countries, in the future. As a hint, we include the table 6 below which suggests that NMSs' governments find it difficult to provide reliable fiscal forecasts. We compared outlined reduction in current expenditure in percentage of GDP between years 2004 and 2005 expressed in CoPr-spring and CoPr-autumn by each NMS. 
Similarly, we calculated envisioned reduction of current expenditure between years 2005 and 2006. Results averaged over EDP and non EDP countries are given in the table 6 .

\begin{tabular}{|c|c|c|c|c|c|c|}
\hline \multicolumn{7}{|c|}{ Table 6: Envisioned expenditure reduction } \\
\hline & \multicolumn{3}{|c|}{2005} & \multicolumn{3}{|c|}{2006} \\
\hline & $\begin{array}{c}\text { CoPr } \\
\text {-spring }\end{array}$ & $\begin{array}{c}\mathrm{CoPr} \\
\text {-autumn }\end{array}$ & difference & $\begin{array}{c}\text { CoPr } \\
\text {-spring }\end{array}$ & $\begin{array}{c}\mathrm{CoPr} \\
\text {-autumn }\end{array}$ & Difference \\
\hline Average & $-1,0$ & $-0,3$ & $0,7^{* *}$ & $-0,9$ & $-1,0$ & 0,1 \\
\hline $\begin{array}{l}\text { EDP } \\
\text { average }\end{array}$ & $-1,3$ & $-0,5$ & $0,8^{* *}$ & $-1,1$ & $-1,3$ & 0,2 \\
\hline $\begin{array}{l}\text { non EDP } \\
\text { average }\end{array}$ & $-0,4$ & $-0,1$ & 0,3 & $-0,5$ & $-0,6$ & 0,1 \\
\hline difference & $0,9^{* *}$ & 0,4 & & 0,6 & $0,7^{*}$ & \\
\hline \multicolumn{7}{|c|}{$\begin{array}{l}\text { Countries that revised their aspirations for 2005: CY; EE; HU; LT; MT; PL; SI; SK. } \\
\text { Countries that reinforced their aspirations for 2006: CY; CZ; EE; HU; LT; MT; PL; SI. }\end{array}$} \\
\hline \multicolumn{7}{|c|}{$\begin{array}{l}\text { Note: Expected change in total current expenditure (total expenditure less capital } \\
\text { formation and other expenditure) expressed in \% of GDP. *** significant on } 1 \% \text {, } \\
* * \text { significant on } 5 \% \text { and } * \text { significant on } 10 \% \text {. } \\
\text { Source: Authors' calculations based on CoPrs of NMSs }\end{array}$} \\
\hline
\end{tabular}

In the spring of 2004, the NMSs expected on average a decrease in their total current expenditure in year 2005 by $1 \%$ of GDP as compared to the year 2004. The EDP countries planned a reduction of $1,3 \%$ of GDP while the non EDP countries had a more moderate goal of cutting expenditures of $0,4 \%$ of GDP. A similar reduction of current expenditures (by 1,1 $\%$ for the EDP and by $0,5 \%$ for non EDP) was scheduled for 2006.

However, when the NMSs submitted their CoPr-autumn things had changed. NMSs downgraded their commitments for year 2005, expecting to reduce their expenditure by only $0,3 \%$ of GDP. As one might have suspected, the EDP countries revised their commitments more significantly - by $0,8 \%$ of GDP. The non EDP that had less ambitious targets for 2005 in the first place, cut them still by $0,3 \%$ of GDP. Eight out of ten NMSs, however, increased their plans for expenditures reduction in 2006.

Given the fact that the EDP countries did not change their projections of budget deficits between CoPr-spring and CoPr-autumn (see tables 3 and 4 and chart 3b), they must have assumed higher tax revenues to compensate for a lack of expenditure cuts. Given relatively high tax revenues in the EDP countries, this strategy does not seem very pro-growth oriented.

\section{RANKING FISCAL POLICIES IN NMSS}

Based on our findings, description of reforms, identified periods of consolidations, composition of NMSs' budgets, application of growth accounting method, derivation of benchmark primary deficit compatible with constant debt to GDP ratio ${ }^{16}$ and information outlined in PEPs and CoPrs, we developed overall index of quality of fiscal policy of every NMS. In this chapter, we describe criteria used and performance of each NMS with respect to those criteria. We also construct four additional sub-indexes, which are designed so as to capture stance of each NMS's fiscal policy in particular areas.

${ }^{16}$ Parts of the criteria we use here are based on our finding from Schneider and Zápal (2005), concretely, criteria no. $8,9,10,11,13$ and 14 . 
What has to be stressed is the fact, that construction and choice of criteria used is highly arbitrary and can be challenged on many grounds. Nevertheless, we believe that our ranking does help to differentiate among the NMS with respect to their fiscal policies. ${ }^{17}$

\section{Criteria no.1 Pension}

We assign one point to each NMS in case it has introduced a three pillar pension system and zero score to all other NMSs. We also add an additional point to those NMSs, which have their first pension pillar based on the defined contribution principle.

\section{Criteria no.2 Health}

We assign one point to each NMS which has undergone considerable health care reform and zero score to all other NMSs.

Criteria no.3

EDP

We assign one point to each NMS which has not been found to violate SGP after EU accession and thus has not been put under EDP and assign zero score to all other NMSs.

\section{Criteria no.4 Revision}

We rank NMSs according to average size of budget deficit revision between submissions of separate PEPs and CoPrs. Highest score is then assigned to NMS which revised its budget deficit least and lowest score to NMS which revised its budget deficit most.

\section{Criteria no.5 Speed}

We take outlined speed of budget deficit reduction four years ahead from CoPrautumn and subtract outlined speed of budget deficit reduction four years ahead from PEP01. We rank NMSs according to the difference and assign a highest score to NMS with the lowest difference and lowest score to NMS with highest difference. NMSs scoring worst are thus those who opted for fastest consolidation in CoPr-autumn relative to speed of consolidation outlined in PEP01.

\section{Criteria no.6 Dependency}

We take demographic dependency ratios in NMSs in year 2001 from European Commission (2003b) and rank NMSs accordingly. Highest score is assigned to NMS with lowest dependency ratio and lowest score to NMS with highest dependency ratio.

\section{Criteria no.7 Fertility}

We take fertility rates in NMSs in year 2003 from Orban and Szapary (2004) and rank NMSs accordingly. Highest score is assigned to NMS with highest fertility rate and lowest score to NMS with lowest fertility rate.

${ }^{17}$ For those criteria, where we rank NMSs, we always assign a score of 2 to NMS with highest rank and lowest score of 0,2 to NMS with lowest rank. Technically, score is the multiple of 0,2 with the rank. While value of two can seem arbitrary, we thing it achieves balance between criteria where ranking is used and where score is assigned directly. Also, choice of different value other than 2 does not change out results significantly (more precisely, best and worst country is independent of choice of value used for multiplication and maximum change in overall position of NMSs for values used for multiplication ranging from 1 to 20 is two positions better or worse). 
We assign a score of one to each NMS with average actual primary deficit in period 2000 through 2004 higher than benchmark primary deficit that ensures constant debt to GDP ratio. All other NMSs are assigned a zero score.

\section{Criteria no.9 Sustainability gap}

We calculate difference between actual and benchmark primary deficit calling it a sustainability gap. We then rank NMSs according to the size of our sustainability gap and assign highest score to NMS with lowest sustainability gap and lowest score to NMS with highest sustainability gap.

\section{Criteria no.10 Stabilizing function}

We count number of years a NMS displayed anti-cyclical fiscal policy over the period 2001 through 2004 based on growth accounting method. ${ }^{18}$ Then we count number of year a NMS displayed pro-cyclical fiscal policy over the same period. We rank NMSs according to difference between the two numbers, rewarding highest score to NMS with highest difference and lowest score to NMS with lowest difference.

\section{Criteria no.11}

Fiscal stance

We count number of year a NMS displayed restrictive fiscal policy over period 2001 through 2004 (taking into account values of net fiscal effort above unity) and number of years NMS displayed expansionary fiscal policy. We than rank NMSs according to difference between the two numbers, assigning highest score to NMS with highest difference and lowest score to NMS with lowest difference.

\section{Criteria no.12 Room to manoeuvre}

We calculate average ratio of general government revenue to GDP in period 2001 through 2004 and rank NMSs accordingly. Highest score is given to NMS with lowest share of revenue in GDP and lowest score is given to NMS with highest share of revenue in GDP.

\section{Criteria no.13 Consolidations}

We calculate number of successful consolidations and subtract number of unsuccessful consolidations ranking NMSs according to the difference. Highest score is then given to NMS with highest difference and lowest score to the NMS with lowest difference.

\section{Criteria no.14 Ability to manoeuvre}

We rank NMSs according to share of open-ended expenditure in their budgets. Highest score is assigned to NMS with lowest share of open-ended expenditure in its budget and lowest score to NMS with highest share of open-ended expenditure in its budget.

\footnotetext{
${ }^{18}$ For details and results, see Schneider and Zápal (2005).
} 


\begin{tabular}{|c|c|c|c|c|c|c|c|c|c|c|c|c|c|c|}
\hline \multicolumn{15}{|c|}{ Table 7: Score of NMSs for each criteria } \\
\hline & $\begin{array}{l}\frac{0}{0} \\
\stackrel{0}{0} \\
0 \\
0\end{array}$ & 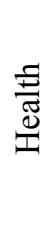 & $\hat{\mathrm{A}}$ & $\frac{\tilde{0}}{\stackrel{0}{a}}$ & $\begin{array}{l}\text { ठ্ } \\
\text { ڤn } \\
\text { की }\end{array}$ & 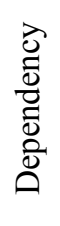 & 吢 & 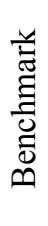 & 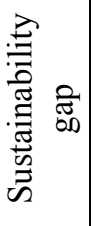 & 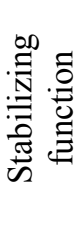 & 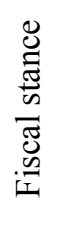 & 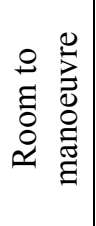 & 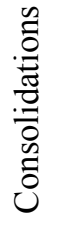 & 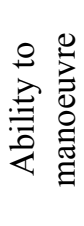 \\
\hline no. & 1 & 2 & 3 & 4 & 5 & 6 & 7 & 8 & 9 & 10 & 11 & 12 & 13 & 14 \\
\hline $\mathrm{CY}$ & 0 & 1 & 0 & 0,2 & 0,8 & 2,0 & 2,0 & 1 & 1,6 & 1,2 & 0,4 & 1,4 & 1,0 & 0,4 \\
\hline $\mathrm{CZ}$ & 0 & 0 & 0 & 0,4 & 0,6 & 1,2 & 0,2 & 0 & 0,2 & 1,2 & 0,4 & 1,0 & 0,2 & 2,0 \\
\hline $\mathrm{EE}$ & 1 & 1 & 1 & 2,0 & 1,8 & 0,2 & 1,6 & 1 & 2,0 & 1,2 & 1,2 & 1,6 & 1,6 & 1,6 \\
\hline $\mathrm{LV}$ & 2 & 1 & 1 & 1,4 & 1,6 & 0,4 & 0,8 & 0 & 1,0 & 1,2 & 1,2 & 1,8 & 0,2 & 1,4 \\
\hline LT & 1 & 1 & 1 & 1,6 & 1,0 & 0,8 & 0,8 & 0 & 1,2 & 0,8 & 0,4 & 2,0 & 1,6 & 1,0 \\
\hline $\mathrm{HU}$ & 1 & 0 & 0 & 0,6 & 1,4 & 0,6 & 1,4 & 1 & 1,8 & 0,2 & 0,4 & 0,6 & 0,6 & 1,2 \\
\hline MT & 0 & 1 & 0 & 0,8 & 0,2 & 1,4 & 1,8 & 0 & 0,4 & 0,8 & 1,6 & 0,8 & 1,6 & 0,2 \\
\hline $\mathrm{PL}$ & 2 & 1 & 0 & 1,8 & 0,4 & 1,6 & 0,8 & 0 & 0,8 & 1,2 & 0,2 & 0,4 & 0,6 & 0,6 \\
\hline SI & 1 & 1 & 1 & 1,0 & 1,2 & 1,0 & 0,6 & 0 & 1,4 & 0,4 & 1,6 & 0,2 & 1,0 & 0,8 \\
\hline SK & 2 & 1 & 0 & 1,2 & 2,0 & 1,8 & 0,4 & 0 & 0,6 & 0,4 & 2,0 & 1,2 & 1,0 & 1,8 \\
\hline
\end{tabular}

Besides computing overall index for fiscal policy, we developed four sub-indexes. First sub-index captures reforms efforts of a NMS and is sum of scores for criteria no. 1, 2, 11 and 13. We call first sub-index reform efforts.

Second sub-index captures impact of demographic ageing on fiscal policy in a NMS and how is it shielded from it and is sum of scores for criteria no. 1, 2, 6, 7, 8, 9, 12 and 14. We call this index ageing impact.

Third sub-index captures whether fiscal policy in NMS performed its functions in stabilizing economy and in providing stable economic environment and is sum of scores for criteria no. 10, 11 and 13 . We call this index fiscal functions.

Last sub-index captures how fiscal policy and policy-makers in NMS stood against SGP criteria, sustainability of their fiscal policies, how they dealt with possible problems and how successful they were and is sum of scores for criteria no. 3, 4, 5, 8, 9, 10, 11 and 13. We call this index past behaviour.

\begin{tabular}{|l|c|c|c|c|c|c|c|c|c|c|}
\hline \multicolumn{10}{|c|}{ Table 8: Ranking fiscal policy in NMSs } \\
\hline & $\begin{array}{c}\text { Reform } \\
\text { efforts }\end{array}$ & Rank & $\begin{array}{c}\text { Ageing } \\
\text { impact }\end{array}$ & Rank & $\begin{array}{c}\text { Fiscal } \\
\text { functions }\end{array}$ & Rank & $\begin{array}{c}\text { Past } \\
\text { behaviour }\end{array}$ & Rank & Total & Rank \\
\hline CY & 2,4 & 3 & 9,4 & 9 & 2,6 & 4 & 6,2 & 5 & 13,0 & 6 \\
\hline CZ & 0,6 & 1 & 4,6 & 1 & 1,8 & 2 & 3,0 & 1 & 7,4 & 1 \\
\hline EE & 4,8 & 9 & 10,0 & 10 & 4,0 & 9 & 11,8 & 10 & 18,8 & 10 \\
\hline LV & 4,4 & 7 & 8,4 & 7 & 2,6 & 4 & 7,6 & 7 & 15,0 & 8 \\
\hline LT & 4,0 & 5 & 7,8 & 6 & 2,8 & 6 & 7,6 & 7 & 14,2 & 7 \\
\hline HU & 2,0 & 2 & 7,6 & 5 & 1,2 & 1 & 6,0 & 4 & 10,8 & 3 \\
\hline MT & 4,2 & 6 & 5,6 & 2 & 4,0 & 9 & 5,4 & 3 & 10,6 & 2 \\
\hline PL & 3,8 & 4 & 7,2 & 4 & 2,0 & 3 & 5,0 & 2 & 11,4 & 4 \\
\hline SI & 4,6 & 8 & 6,0 & 3 & 3,0 & 7 & 7,6 & 7 & 12,2 & 5 \\
\hline SK & 6,0 & 10 & 8,8 & 8 & 3,4 & 8 & 7,2 & 6 & 15,4 & 9 \\
\hline Note: Highest score implies higher rank and denotes “better" fiscal policy. & & & \\
\hline
\end{tabular}


Although rank of individual NMSs according to various sub-indexes varies, taking all the criteria as a whole gives relatively clear picture. There is a group of countries with responsible fiscal policy and strong reform efforts where Estonia, Latvia, Lithuania and Slovakia belong. On the other hand, there is a group of countries with irresponsible fiscal policy making and lax approach to reforms, where Czech Republic, Malta and Hungary belong based on the overall index. The Czech Republic stands out as an outlier, with the worst results in most indicators and almost no demonstrated reform activity.

\section{CONCLUSION}

Summarising our analysis of politics of fiscal consolidations, we have seen that many NMSs implemented important reforms over the past years probably most important being pension systems reforms. Some of the NMSs have an impressive reform record behind them, reforming most of the public budget programmes and reaping benefits of reforms in balanced and sustainable budgets. But also many important steps remain to be done. Apart from rather slow progress in health care system reforms in many countries, there seems to be a need to reduce generosity of public sector wages and social benefit systems that repeatedly put a strong pressure on public finance in many NMSs and have been a source of unexpected budgetary developments. Many reforms also display low quality of implementation burdened, above all, by political disputes.

Evidence from PEPs and CoPrs shows further that EDP countries revise their budget deficits more often and by larger values than non EDP countries, aiming subsequently for stronger future consolidations. Such practices allowed governments in EDP countries to postpone politically costly consolidations, implementing stop-and-go strategy later on. Measures implemented just before or after EDP initiation show clear focus on bringing budget deficits under control. Many these consolidations, however, seem to rely on abrupt measures and neglect a long-term perspective of coherent and comprehensive reforms. Due to this these consolidations might be hard to sustain politically.

Fiscal outlook in several NMSs is rather worrying in this context. The NMSs expect to run deficit of about $2 \%$ of GDP in 2006 which gives them much smaller margin for fiscal policy relaxation. Given the NMSs' problems in managing fiscal policy and their inclination to run pro-cyclical fiscal policies, odds are not very promising. Moreover, if the NMSs do qualify for the EMU membership, political will to keep fiscal deficits under control may fade as it did in the EUR-15 countries and then the NMSs may face high deficits again.

We believe that the two latter effects, i.e. the tendency of postponing structural reforms and potential malaise following the expected EMU membership, may make for a dangerous brew, especially in the already troubled EDP countries. These six countries (Hungary, Poland, Czech Republic, Malta, Cyprus, the exception being Slovakia) demonstrate their failure to put fiscal policy in order even at time of exceptionally supportive environment: economic performance has been relatively robust in last few years and the countries are motivated by cherished EMU membership. Still, they run fiscal deficits averaging $4 \%$ of GDP. One may just fear how high these deficits may become in a few years time... 


\section{REFERENCES}

- European Commission, (2002a) "Evaluation of the 2001 pre-accession economic programmes of candidate countries", Enlargement Papers, no.7, European Commission, Brussels, 2002.

- European Commission, (2002b) "Evaluation of the 2002 pre-accession economic programmes of candidate countries", Enlargement Papers, no.14, European Commission, Brussels, 2002.

- European Commission, (2003a) "Evaluation of the 2002 pre-accession economic programmes of candidate countries", Enlargement Papers, no.20, European Commission, Brussels, 2003.

- European Commission, (2003b) "Social Protection in the 13 Candidate Countries: A Comparative Analysis", European Commission, Brussels, 2003.

- $\quad$ European Commission, (2004a) "Public Finances in EMU 2004“, European Commission, Brussels, European Economy Reports and Studies, no.3, 2004.

- European Commission, (2004b) "General Government Data, Part II: Table by Series, Autumn 2004“, European Commission, Brussels, 2004.

- Gregor, M., (2004) "Governing Fiscal Commons in the Enlarged EU“, Proceedings of conference "Development of Czech Society in EU“" organized by Charles University, Prague, $21^{\text {st }}-23^{\text {rd }}$ September, 2004.

- Hagen, von J., Hallett, A.H. and Strauch, R., (2001) "Budgetary Consolidations in EMU", European Commission, Brussels, Economic papers, no.148, 2001.

- Orban, G. and Szapary, G., (2004) "The Stability and Growth Pact from the Perspective of the New Member States", William Davidson Institute working paper, no.709, 2004.

- Roubini N. and Sachs J., (1989), "Political and Economic Determinants of Budget Deficits in the Industrial Democracies", European Economic Review, vol.33, 1989, 903-938.

- $\quad$ Schneider, O. and Zápal, J, (2005) "Fiscal Policy in New EU Member States - Go East Prudent Man “, CESIfo working paper, no.1486, 2005.

- $\quad$ Strauch, R., Hallerberg, M. and Hagen, von J., (2004) "Budgetary Forecasts in Europe - The Track Record of Stability and Convergence Programmes", ECB working paper, no.307, 2004.

- Ylaoutinen, S., (2004) "Fiscal Frameworks in the Central and Eastern European Countries", Finish Ministry of finance discussion paper, no.72, 2004. 


\section{CESifo Working Paper Series}

(for full list see www.cesifo-group.de)

1593 Jim Malley, Apostolis Philippopoulos and Ulrich Woitek, Electoral Uncertainty, Fiscal Policy and Macroeconomic Fluctuations, November 2005

1594 Assar Lindbeck, Sustainable Social Spending, November 2005

1595 Hartmut Egger and Udo Kreickemeier, International Fragmentation: Boon or Bane for Domestic Employment?, November 2005

1596 Martin Werding, Survivor Benefits and the Gender Tax Gap in Public Pension Schemes: Observations from Germany, November 2005

1597 Petra Geraats, Transparency of Monetary Policy: Theory and Practice, November 2005

1598 Christian Dustman and Francesca Fabbri, Gender and Ethnicity - Married Immigrants in Britain, November 2005

1599 M. Hashem Pesaran and Martin Weale, Survey Expectations, November 2005

1600 Ansgar Belke, Frank Baumgaertner, Friedrich Schneider and Ralph Setzer, The Different Extent of Privatisation Proceeds in EU Countries: A Preliminary Explanation Using a Public Choice Approach, November 2005

1601 Jan K. Brueckner, Fiscal Federalism and Economic Growth, November 2005

1602 Steven Brakman, Harry Garretsen and Charles van Marrewijk, Cross-Border Mergers and Acquisitions: On Revealed Comparative Advantage and Merger Waves, November 2005

1603 Erkki Koskela and Rune Stenbacka, Product Market Competition, Profit Sharing and Equilibrium Unemployment, November 2005

1604 Lutz Hendricks, How Important is Discount Rate Heterogeneity for Wealth Inequality?, November 2005

1605 Kathleen M. Day and Stanley L. Winer, Policy-induced Internal Migration: An Empirical Investigation of the Canadian Case, November 2005

1606 Paul De Grauwe and Cláudia Costa Storti, Is Monetary Policy in the Eurozone less Effective than in the US?, November 2005

1607 Per Engström and Bertil Holmlund, Worker Absenteeism in Search Equilibrium, November 2005

1608 Daniele Checchi and Cecilia García-Peñalosa, Labour Market Institutions and the Personal Distribution of Income in the OECD, November 2005 
1609 Kai A. Konrad and Wolfgang Leininger, The Generalized Stackelberg Equilibrium of the All-Pay Auction with Complete Information, November 2005

1610 Monika Buetler and Federica Teppa, Should you Take a Lump-Sum or Annuitize? Results from Swiss Pension Funds, November 2005

1611 Alexander W. Cappelen, Astri D. Hole, Erik Ø. Sørensen and Bertil Tungodden, The Pluralism of Fairness Ideals: An Experimental Approach, December 2005

1612 Jack Mintz and Alfons J. Weichenrieder, Taxation and the Financial Structure of German Outbound FDI, December 2005

1613 Rosanne Altshuler and Harry Grubert, The Three Parties in the Race to the Bottom: Host Governments, Home Governments and Multinational Companies, December 2005

1614 Chi-Yung (Eric) Ng and John Whalley, Visas and Work Permits: Possible Global Negotiating Initiatives, December 2005

1615 Jon H. Fiva, New Evidence on Fiscal Decentralization and the Size of Government, December 2005

1616 Andzelika Lorentowicz, Dalia Marin and Alexander Raubold, Is Human Capital Losing from Outsourcing? Evidence for Austria and Poland, December 2005

1617 Aleksander Berentsen, Gabriele Camera and Christopher Waller, Money, Credit and Banking, December 2005

1618 Egil Matsen, Tommy Sveen and Ragnar Torvik, Savers, Spenders and Fiscal Policy in a Small Open Economy, December 2005

1619 Laszlo Goerke and Markus Pannenberg, Severance Pay and the Shadow of the Law: Evidence for West Germany, December 2005

1620 Michael Hoel, Concerns for Equity and the Optimal Co-Payments for Publicly Provided Health Care, December 2005

1621 Edward Castronova, On the Research Value of Large Games: Natural Experiments in Norrath and Camelot, December 2005

1622 Annette Alstadsæter, Ann-Sofie Kolm and Birthe Larsen, Tax Effects, Search Unemployment, and the Choice of Educational Type, December 2005

1623 Vesa Kanniainen, Seppo Kari and Jouko Ylä-Liedenpohja, Nordic Dual Income Taxation of Entrepreneurs, December 2005

1624 Lars-Erik Borge and Linn Renée Naper, Efficiency Potential and Efficiency Variation in Norwegian Lower Secondary Schools, December 2005 
1625 Sam Bucovetsky and Andreas Haufler, Tax Competition when Firms Choose their Organizational Form: Should Tax Loopholes for Multinationals be Closed?, December 2005

1626 Silke Uebelmesser, To go or not to go: Emigration from Germany, December 2005

1627 Geir Haakon Bjertnæs, Income Taxation, Tuition Subsidies, and Choice of Occupation: Implications for Production Efficiency, December 2005

1628 Justina A. V. Fischer, Do Institutions of Direct Democracy Tame the Leviathan? Swiss Evidence on the Structure of Expenditure for Public Education, December 2005

1629 Torberg Falch and Bjarne Strøm, Wage Bargaining and Political Strength in the Public Sector, December 2005

1630 Hartmut Egger, Peter Egger, Josef Falkinger and Volker Grossmann, International Capital Market Integration, Educational Choice and Economic Growth, December 2005

1631 Alexander Haupt, The Evolution of Public Spending on Higher Education in a Democracy, December 2005

1632 Alessandro Cigno, The Political Economy of Intergenerational Cooperation, December 2005

1633 Michiel Evers, Ruud A. de Mooij and Daniel J. van Vuuren, What Explains the Variation in Estimates of Labour Supply Elasticities?, December 2005

1634 Matthias Wrede, Health Values, Preference Inconsistency, and Insurance Demand, December 2005

1635 Hans Jarle Kind, Marko Koethenbuerger and Guttorm Schjelderup, Do Consumers Buy Less of a Taxed Good?, December 2005

1636 Michael McBride and Stergios Skaperdas, Explaining Conflict in Low-Income Countries: Incomplete Contracting in the Shadow of the Future, December 2005

1637 Alfons J. Weichenrieder and Oliver Busch, Artificial Time Inconsistency as a Remedy for the Race to the Bottom, December 2005

1638 Aleksander Berentsen and Christopher Waller, Optimal Stabilization Policy with Flexible Prices, December 2005

1639 Panu Poutvaara and Mikael Priks, Violent Groups and Police Tactics: Should Tear Gas Make Crime Preventers Cry?, December 2005

1640 Yin-Wong Cheung and Kon S. Lai, A Reappraisal of the Border Effect on Relative Price Volatility, January 2006

1641 Stefan Bach, Giacomo Corneo and Viktor Steiner, Top Incomes and Top Taxes in Germany, January 2006 
1642 Johann K. Brunner and Susanne Pech, Optimum Taxation of Life Annuities, January 2006

1643 Naércio Aquino Menezes Filho, Marc-Andreas Muendler and Garey Ramey, The Structure of Worker Compensation in Brazil, with a Comparison to France and the United States, January 2006

1644 Konstantinos Angelopoulos, Apostolis Philippopoulos and Vanghelis Vassilatos, RentSeeking Competition from State Coffers: A Calibrated DSGE Model of the Euro Area, January 2006

1645 Burkhard Heer and Bernd Suessmuth, The Savings-Inflation Puzzle, January 2006

1646 J. Stephen Ferris, Soo-Bin Park and Stanley L. Winer, Political Competition and Convergence to Fundamentals: With Application to the Political Business Cycle and the Size of Government, January 2006

1647 Yu-Fu Chen, Michael Funke and Kadri Männasoo, Extracting Leading Indicators of Bank Fragility from Market Prices - Estonia Focus, January 2006

1648 Panu Poutvaara, On Human Capital Formation with Exit Options: Comment and New Results, January 2006

1649 Anders Forslund, Nils Gottfries and Andreas Westermark, Real and Nominal Wage Adjustment in Open Economies, January 2006

1650 M. Hashem Pesaran, Davide Pettenuzzo and Allan G. Timmermann, Learning, Structural Instability and Present Value Calculations, January 2006

1651 Markku Lanne and Helmut Luetkepohl, Structural Vector Autoregressions with Nonnormal Residuals, January 2006

1652 Helge Berger, Jakob de Haan and Jan-Egbert Sturm, Does Money Matter in the ECB Strategy? New Evidence Based on ECB Communication, January 2006

1653 Axel Dreher and Friedrich Schneider, Corruption and the Shadow Economy: An Empirical Analysis, January 2006

1654 Stefan Brandauer and Florian Englmaier, A Model of Strategic Delegation in Contests between Groups, January 2006

1655 Jan Zápal and Ondřej Schneider, What are their Words Worth? Political Plans and Economic Pains of Fiscal Consolidations in New EU Member States, January 2006 